\title{
TRANSFORMATION OF PSEUDOMONAS AERUGINOSA BY PLASMID DNA
}

\author{
YUMIKO SANO AND MAKOTO KAGEYAMA \\ Mitsubishi-Kasei Institute of Life Sciences, Machida, Tokyo 194, Japan
}

(Received June 9, 1977)

Genetic transformation of $P$. aeruginosa by the drug-resistance factor DNA (RP4) is reported. Transformants retain all the drug-resistance characteristics present in the parent plasmid.

Genetic transformation has proved to be one of valuable techniques in studying genetic fine structures of several microorganisms. $\operatorname{KHAN}$ and $\operatorname{Sen}(1,2)$ claimed to have succeeded in genetic transformation with chromosomal DNA in several strains of Pseudomonas aeruginosa and P. fluorescens. However, this work could not be repeated in our hands nor by BOOKER and LOUTIT (3). Recently it was shown that $\mathrm{CaCl}_{2}$ treatment was effective for the plasmid-mediated transformation in gram-negative bacteria such as $E$. coli, $S$. typhimurium and $P$. putida (4-6). In this paper, we report the transformation in $P$. aeruginosa with a drug-resistance factor DNA.

\section{MATERIALS AND METHODS}

The bacterial strains and plasmids used in these experiments are listed in Table 1. RP4 is a large drug-resistance factor which specifies resistance to carbenicillin, kanamycin, neomycin, and tetracycline, and sensitivity to phage PRR1 (7) and is known to be transmissible between $E$. coli and $P$. aeruginosa by conjugation $(7,8)$.

The procedure used for the isolation of plasmid DNA was according to that of Matsubara, TAKagi, and Mukai (9). Concentration of DNA was determined by the absorption at $260 \mathrm{~nm}$. $\quad P$. aeruginosa and $E$. coli were grown in a nutrient broth at $37^{\circ}$. At the late exponential phase, the cells were harvested by centrifugation and washed once with $100 \mathrm{mM} \mathrm{MgCl}$ ( 0.5 volume of the original culture). The cells were centrifuged and resuspended in one-half the original volume of $30 \mathrm{mM} \mathrm{CaCl}_{2}$, kept at $0^{\circ}$ for $20 \mathrm{~min}$. After centrifugation at $0^{\circ}$, the cells were resuspended in 0.1 volume of $30 \mathrm{mM} \mathrm{CaCl}_{2}$. Competent cells $(0.2 \mathrm{ml})$ thus obtained were mixed with $0.1 \mathrm{ml}$ of RP4 DNA solution in TEN buffer ( $0.02 \mathrm{M}$ Tris(hydroxy- 
Table 1. Bacterial strains used.

\begin{tabular}{|c|c|c|}
\hline Bacterial strains & Properties & Source \\
\hline E. coli $\mathrm{C} 600$ & $\mathrm{thr}^{-}, \mathrm{leu}^{-}, \mathrm{thi}^{-}$ & \\
\hline E. coli C600 (RP4) & $\begin{array}{l}\text { thr- } \mathrm{leu}^{-}, \mathrm{thi}^{-}, \mathrm{Cb}^{\mathrm{r}}, \mathrm{Km}^{\mathrm{r}} \\
\mathrm{Nm}^{\mathrm{r}}, \mathrm{Tc}^{\mathrm{r}}\end{array}$ & this laboratory \\
\hline E. coli $\mathrm{C} 600 \mathrm{res}^{-} \mathrm{mod}^{-}$ & thr- $\mathrm{leu}^{-}, \mathrm{thi}^{-}, \mathrm{res}^{-}, \mathrm{mod}^{-}$ & T. Tanaka \\
\hline P. aeruginosa $\mathrm{P} 14$ & prototroph & this laboratory \\
\hline P. aeruginosa P14 (RP4) & prototroph, $\mathrm{Cb}^{\mathrm{r}}, \mathrm{Km}^{\mathrm{r}}, \mathrm{Nm}^{\mathrm{r}}, \mathrm{Tc}^{\mathrm{r}}$ & this laboratory \\
\hline P. aeruginosa $\mathrm{M} 12$ & $\operatorname{trp} p^{-}$ & this laboratory (PAO subline) \\
\hline P. aeruginosa PU21 (RP4) & $\begin{array}{l}\text { leu } \\
- \\
\mathrm{Nm}^{\mathrm{r}}, \mathrm{Tc}^{-}\end{array}$ & G.A. Jacoby (PAO subline) \\
\hline
\end{tabular}

Abbreviations used: $\mathrm{Cb}$, carbenicillin; $\mathrm{Km}$, kanamycin; $\mathrm{Nm}$, neomycin; $\mathrm{Tc}$, tetracycline; res, restriction; mod, modification.

methyl)-aminomethane ( $\mathrm{pH}$ 8.0)-1 mM EDTA-0.02 $\mathrm{M} \mathrm{NaCl}$ )-30 $\mathrm{mM} \mathrm{CaCl}_{2}$ and incubated at $0^{\circ}$. After $60 \mathrm{~min}$, bacteria were subjected to a heat pulse at $42^{\circ}$ for 2-10 min, chilled, and then plated directly onto a nutrient agar containing carbenicillin. When transformants were selected by other antibiotics besides carbenicillin, the mixture was diluted 10 times with a nutrient broth containing $0.4 \%$ $\mathrm{KNO}_{3}$ and incubated overnight at $37^{\circ}$ before plating. Transformants were selected on a nutrient agar containing carbenicillin $500 \mu \mathrm{g} / \mathrm{ml}$, kanamycin $300 \mu \mathrm{g} / \mathrm{ml}$, or tetracycline $150 \mu \mathrm{g} / \mathrm{ml}$ in the case of $P$. aeruginosa and carbenicillin $500 \mu \mathrm{g} / \mathrm{ml}$ in the case of $E$. coli. Washing cells with $100 \mathrm{mM} \mathrm{MgCl}_{2}$ was most effective compared to washings with 10 and $100 \mathrm{mM} \mathrm{MgCl}_{2}, \mathrm{CaCl}_{2}$, or $\mathrm{NaCl}$. The optimum con-

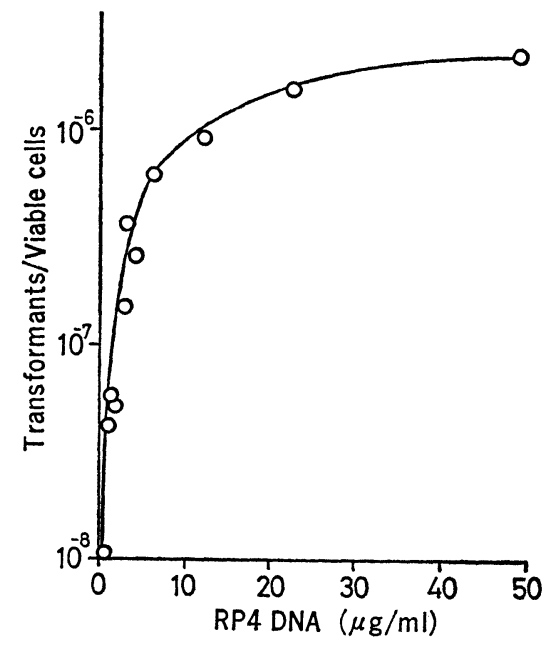

Fig. 1. Effect of concentration of $\mathrm{R}$ factor DNA on transformation frequency. Various concentration of RP4 DNA isolated from PU21 (RP4) was added to $\mathrm{CaCl}_{2}$ treated $P$. aeruginosa M12. The transformation frequency was determined by counting carbenicillin-resistant colonies. 
centration of $\mathrm{CaCl}_{2}$ was $30 \mathrm{~mm}$ and could be substituted by the same concentration of $\mathrm{MgCl}_{2}$.

\section{RESULTS AND DISCUSSION}

A typical result of transformation with this procedure using purified RP4 DNA is shown in Fig. 1. The transformation frequency depended on the DNA concentration and was about $10^{-6}$ per viable cell at $10 \mu \mathrm{g} / \mathrm{ml}$ DNA. Viability after $\mathrm{CaCl}_{2}$ treatment was $30-40 \%$. The frequency between different $P$. aeruginosa strains showed somewhat reduced values, possibly because of restriction (Table 2).

Table 2. Comparison of transformation frequency between $P$. aeruginosa strains.

\begin{tabular}{lcl} 
Source of DNA & \multicolumn{2}{c}{ Recipient cells } \\
\cline { 2 - 3 } & M12 (PAO) & P14 \\
\hline PU21 (RP4) (PAO) & $1^{*}$ & 0.23 \\
P14 (RP4) & 0.02 & $1^{* *}$ \\
\hline
\end{tabular}

Each recipient was treated with plasmid DNA $(23-25 \mu \mathrm{g} / \mathrm{ml})$ from the same or different strain. Transformants were selected with carbenicillin. Ratios of transformation frequency are shown.

* $6.5 \times 10^{-7} /$ viable cell, $* * 2.3 \times 10^{-7} /$ viable cell.

Table 3. Transformation efficiency between P. aeruginosa and E. coli.

\begin{tabular}{|c|c|c|c|}
\hline \multirow{2}{*}{ Source of DNA } & \multicolumn{3}{|c|}{ Recipient cells } \\
\hline & P. aeruginosa $\mathrm{P} 14$ & E. coli $\mathrm{C} 600$ & E.coli $\mathrm{C} 600 \mathrm{res}^{-} \mathrm{mod}^{-}$ \\
\hline P. aeruginosa P14 (RP4) & 1 & $4 \times 10^{-4}$ & 1 \\
\hline E. coli C600 (RP4) & none & 1 & 1 \\
\hline
\end{tabular}

Recipients were treated with plasmid DNA $(45 \mu \mathrm{g} / \mathrm{ml})$ from either $P$. aeruginosa or $E$. coli, and frequencies of $\mathrm{Cb}^{\mathrm{r}}$ transformation were compared.

The restriction was much more apparent between $P$. aeruginosa and $E$. coli, while a restriction-negative $E$. coli strain was transformed with a high frequency (Table 3). So far tested, all the transformants selected by carbenicillin showed resistance to other antibiotics as well and in case of PAO strains also showed sensitivity to phage PRR1.

Any transformants of chromosomal markers were not detected by this procedure with the whole bacterial DNA in P. aeruginosa PAO, contrary to the report of $\operatorname{KHAN}$ and $\operatorname{SEN}(1,2)$.

The procedure for the genetic transformation of $P$. aeruginosa described here suggests a possibility of cloning composite plasmids constructed in vitro from genes of $P$. aeruginosa and other species.

This study was presented at the 49th Annual Meeting of the Japanese Biochemical Society, Sept. 2, $1976(10)$. While this work was being performed, a report 
appeared that referred to the transformability of $P$. aeruginosa with plasmid DNA but no details were given (11).

\section{REFERENCES}

1) N. C. Khan and S. P. Sen, J. Gen. Microbiol., 49, 201 (1967).

2) N. C. Khan and S. P. Sen, J. Gen. Microbiol., 83, 251 (1974).

3) R. J. Booker and J. S. Loutit, Genet. Res., 23, 145 (1974).

4) S. N. Cohen, A. C. Y. Chang, and L. Hsu, Proc. Natl. Acad. Sci. U.S.A., 69, 2110 (1972).

5) E. M. LeDerberg and S. N. Cohen, J. Bacteriol., 119, 1072 (1974).

6) A. M. Chakrabarty, J. R. Mylroie, D. A. Friello, and J. G. Vacca, Proc. Natl. Acad. Sci. U.S.A., 72, 3647 (1975).

7) R. H. Olsen and P. ShIPLEY, J. Bacteriol., 113, 772 (1973).

8) N. Datta, R. W. Hedges, E. J. Shaw, R. B. Sykes, and M. H. Richmond, J. Bacteriol., 108, 1244 (1971).

9) K. Matsubara, Y. Takagi, and T. Mukai, J. Virol., 16, 479 (1975).

10) Y. SANo and M. KaGeYAMA, Seikagaku, 48, 574 (1976).

11) R. H. Olsen and P. Shipley, J. Bacteriol., 125, 837 (1976). 